\title{
The Mixed Model of Teachers' Evaluation in Secondary Schools
}

\section{El modelo mixto de evaluación de los docentes en las escuelas secundarias}

\author{
Yury Frolov \\ jury_frolov@mail.ru \\ https://orcid.org/0000-0001-8737-6091
}

Doctor of Economics, Professor, Moscow City University, Moscow, Russia.

Recibido: $15 / 05 / 21$

Aceptado: 11/07/21

\begin{abstract}
Schools face the need to create a system for managing the performance of teaching employees whose activities are specific, difficult to formalize, and subjected to experiments with different degrees of success throughout the world. This paper deals with providing and management of teacher's evaluation in Russian schools. The purpose of the study is to develop a teacher evaluation model based on professional qualities and performance indicators. The results of the study were tested on the basis of a survey of teachers after the implementation of the proposed system of assessment tools and evaluation methods. According to teachers, the new system contributes to their continuous professional development and, therefore, to the sustainable development of the educational organization in a competitive environment. The proposed methodology for teachers' evaluation clarifies the general data and meets their expectations, expectations of students and management in terms of correspondence with the development strategies of educational organizations.
\end{abstract}

Keywords: quality of education, teacher evaluation, professional qualities, results of activity, HRM system (HRMS).

\section{Resumen}

Las escuelas enfrentan la necesidad de crear un sistema de gestión del desempeño de los empleados docentes cuyas actividades son específicas, difíciles de formalizar y sometidas a experimentos con diferentes grados de éxito en todo el mundo. Este documento trata de la provisión y gestión de la evaluación de los profesores en las escuelas rusas basándose en la estructuración de los indicadores de evaluación de la actividad de los profesores en dos grupos: cualidades profesionales e indicadores de 
desempeño. El estudio sugiere modelos de herramientas de evaluación, así como prueba los métodos para evaluar a los docentes como elementos de un HRMS (sistema de gestión de recursos humanos) integrado en una organización educativa, proporciona un enfoque y criterios para medir indicadores que caracterizan tanto las competencias (habilidades) como los resultados de la actividad docente. El experimento realizado para evaluar la confiabilidad de los modelos propuestos que simplificaron los procedimientos de evaluación y una encuesta a los docentes que participaron en el experimento han demostrado que los modelos desarrollados y HRMS, según los propios docentes, contribuyen a su desarrollo profesional continuo y, por ende - desarrollo sostenible de una organización educativa en un entorno competitivo. La metodología propuesta para la evaluación de los docentes aclara los datos generales y cumple con sus expectativas, expectativas de los estudiantes y la gestión en términos de correspondencia con las estrategias de desarrollo de las organizaciones educativas.

Palabras clave: calidad de la educación, evaluación docente, gestión del desempeño general, evaluación de la actividad, cualidades profesionales, resultados de la actividad, sistema de gestión de recursos humanos (HRMS).

\section{Introduction}

The quality of teachers determines the effectiveness of the education system and the success of graduates of general education institutions. Quality education requires professional specialists who are competitive in the labour market, proficient in their profession and ready for continuous professional development. In this regard, schools are faced with the need to create a system to manage the performance of teaching staff.

This study examines the provision and management of teacher performance evaluation in Russian schools based on the structuring of teacher performance evaluation indicators. The study proposes models of assessment tools and tested methods for teacher evaluation as elements of an integrated human resource management system (HRMS) in an educational organization; it proposes an approach and criteria for measuring indicators that characterize both competencies (abilities) and performance of a teacher.

\section{Literature Review}

Financial investments in educational institutions will be meaningless without highperformance work and management systems providing quality training and organizational effectiveness (Maroufkhani et al, 2015). The relevance of this study is determined by the need to ensure a consistently high quality of the educational process according to changes in the management of Russian budgetary educational organizations associated with transition to normative per capita financing, which contributes to formation of a competitive environment in the market of educationa I services. It is based on the choice of school by students' parents. 
Yury Frolov.

It is impossible to reveal teachers' effectiveness only based on feedback (Chianese, 2015). The tools used to measure teachers' performance should provide an opportunity to evaluate both competence and the results of work (Armstrong and Baron, 1998) within the so-called mixed model including the groups of indicators (Berger and Berger, 2000). Stimulation based solely on the results of activities "leaves out" previous results; based solely on competence does not help an educational organization to achieve results that are meaningful to interest groups.

Professional qualities are a set of groups of indicators (qualifications, knowledge, special personal qualities) important for professional activity and affect the degree of success (or failure) in the performance of work. The results of the activity are the key indicators of teacher's performance during the reporting period. They, like student performance indicators, depend on changing state standards and estimates (Backes et al., 2018) and are not completely defined by standards, as in the case of CCSS rollout expressed in the one-year suspense of the use of test-based metrics in teacher evaluations in the USA in 2014 , as the accountability of teachers in the context of recently adopted experimental standards and assessments was not fair (Chang, 2013), while the standard itself was limited by demonstration of what students are expected to learn.

Prior to launching programs of teachers' professional development, along with processes of their evaluation and reward, it is desirable to use a mixed model of measurable indicators. This study successfully applied the HRMS and tested a system of indicators generating incentives for teachers to their constant professional development designed to measure and increase the effectiveness of teachers giving an idea of achievement of academic and educational goals. Ideally, general education school (GES) teachers should understand all the stages of their professional development and be oriented toward professional self-development, to receive support from mentors and administration of institutions. That is, standards should be based not only on what teachers need to know, but also what they need to do (Sandholtz and Shea, 2012) to meet the diverse and changing needs of learners, to analyze and adapt the methodology. HRM does not only aim to monitor teachers' activities but also increases school effectiveness, based on maintaining an atmosphere of trust and collegiality (Shirrell, 2016). Publications on the effectiveness of HRM in educational organizations (Çevik et al., 2015, Vekeman et al., 2014), characterize them mostly positive. Some studies indicate their shortcomings and even affirm the negative impact of HRM on teachers' activities (Andreeva and Sergeeva, 2016; Mariappanadar 2014). HRM practices should be sufficiently developed and meet the principles of openness and clarity, be perceived as clear and understandable by personnel (Runhaar, 2017), since ambiguity will lead to attempts of self-interpretation of standards and, accordingly, to different results.

Hypothesis: a mixed model of assessment tools integrating both professional and performance indicators is adequate to specifics of Russian teachers' activities. To ensure success in activities, a teacher should demonstrate professionally significant qualities (differentiating competencies), which are not typical for other types of activities. 
The study aims to develop and test the methods and models of teachers' evaluation within the framework of an integrated (mixed) system including both the results of activities teacher's professional qualities.

\section{Methodology}

The study was conducted as a part of experiment on creation of tools for attestation and GES teachers' evaluation. In accordance with the developed competence evaluation tools, 223 primary, secondary and senior school teachers of 46 educational organizations have completed their attestation in Moscow in 2006-2011. The total number of respondents involved in the 360-degree evaluation (Ward, 1997) amounted to 2875 people, including 1978 teachers, 541 parents, 275 heads and deputy heads of public organizations, 39 specialists from methodological centers, 34 professional valuers and 8 specialists from the Office for the regional (Moscow).

The study included:

- development of evaluation tools in a mixed model;

- approbation of the developed models in the experiment;

- analysis of the possibility to use the evaluation results to meet the challenge of teachers' professional development.

We use Roberts' idea (1997) to distinguish the differentiating and threshold competencies in teachers' evaluation and school management. Differentiating competencies are identical to the basic ones and identify best teachers according to the level of the educational activity performance. Thresholds competencies presuppose a minimum level of their development, which allows teachers to perform activities. Young specialists or specialists who come to work at an educational organization after their professional retraining with a non-major basic education have threshold competencies.

Teachers' competencies as elements of their professional qualities are divided into two clusters (Ryabov et al., 2012):

1) the "core" of basic pedagogical competencies invariant to the subject or methodological specialization of a teacher: personal qualities of a person critical for educational activity demonstrated in various working situations.

2) the cluster of variable competencies depending on the profile of activity, for example, subject specialization; the invariant "core competencies" determine the degree of a person's predisposition to educational activity; the structure and composition of the core competencies can form the basis of the general (accepted by the community of educators) understanding of the standard features of a successful teacher. 
The model of teacher's basic competencies implies the division into levels of threshold and differentiating competencies obtained from the results of studies performed at MCU (Moscow City University) (Table 1).

Table 1. An approximate model of the basic teacher competencies (Ryabov et al, 2012)

\begin{tabular}{lc}
\multicolumn{1}{c}{ Basic competencies } & $\begin{array}{c}\text { The relative frequency with which the } \\
\text { competence distinguishes between the } \\
\text { best and average teachers (Competence } \\
\text { weight) }\end{array}$ \\
\hline Impact & $\mathbf{X X X X X}$ \\
\hline Development of others & $\mathbf{X X X X \mathbf { X }}$ \\
\hline Interpersonal understanding & $\mathbf{X X X X}$ \\
\hline $\begin{array}{l}\text { Enjoyment from work and dedication to the educational } \\
\text { institution }\end{array}$ & $\mathbf{X X X}$ \\
\hline Self-control & $\mathbf{X X X}$ \\
\hline Customer orientation (educational services) & $\mathbf{X X X}$ \\
\hline Teamwork and cooperation & $\mathbf{X X X}$ \\
\hline Analytical thinking & $\mathbf{X X X}$ \\
\hline Conceptual thinking & $\mathbf{X X}$ \\
\hline Initiative & $\mathbf{X X}$ \\
\hline Flexibility & $\mathbf{X X}$ \\
\hline Achievements orientation & $\mathbf{X}$ \\
\hline Opinionated and judgmental thinking / insistence & $\mathbf{X}$ \\
\hline Basic job knowledge & $\mathbf{X}$ \\
\hline
\end{tabular}

The weight indicator shows the relative frequency with which the given competencies can separate teacher's differentiating (significant) and threshold competencies. Behavioral indicators of differentiating competencies reflect the level of their emotional intelligence.

The impact indicates recognition individual needs of students (pupils) and builds an effective strategy for involving children in the educational process, influences students.

Development of others is a part of the core pedagogical competence (Çevik et al., 2015, Fenwick 2016) reflecting teacher's faith in the potential of students, humanistic learning, manifested in promoting the independent work of learners and providing a benevolent feedback.

Enjoyment from work reflects devotion to the school's mission (purpose), sense of responsibility and satisfaction with the idea of students effectively learning the educational material under their guidance.

Self-control reflects demonstrating endurance and tact, even in crises.

Competencies' evaluation, management areas dedicated to measuring the performance of an organization and its intangible assets, as well as the performance management 
¿eduweb

Revista de Tecnología de Información y Comunicación en Educación • Volumen 15, Nㅜ 2. Mayo-agosto 2021

(Hubert, 2003; Lawson, 1995) should become the methodological basis for development of assessment tools and standards for professional work of teachers.

The idea of balanced indicators (Niven, 2003) is to establish links between strategic initiatives and indicators characterizing human capital and the financial performance of a business organization. This connection is generally by decomposition of organization's initiatives and indicators into four clusters (prospects): finances, customers, internal business processes and the personnel competence and morale.

The "Balance of Interests" model is more preferable: finance shift to the lower level of the hierarchy acquiring the character of a providing group of indicators in the processes of meeting expectations of all the major interest groups, primarily consumers. Human capital and, above all, professionalism are the priority for strategic goals of innovative companies, scientific and educational organizations that influence the improvement of consistency and the quality (Parks-Leduc et al., 2017; Pogodzinski, 2016) of training programs specialists.

\section{Results and Discussion}

Following the results of the study carried out at MCU, the model of evaluation tools (indicators) constitutes the invariant "core" of GES teacher competencies (primary school teachers, subject teachers) and includes the clusters of teacher competencies:

- professionally important personal qualities of a teacher;

- information basis of the teacher's activity;

- setting goals and objectives of educational activity;

- motivation of training activities;

- developing programs of activities and adoption of pedagogical decisions;

- organization of training activities.

The names of competency clusters correspond to the names proposed by Shadrikov and Kuznetsov (2010). Descriptions of behavioral indicators reflect the results of conducted experiments and studies. Each group (cluster) of teacher's competencies is presented by the necessary and sufficient competencies for measuring the performance indicators (indicators). Each cluster includes 3-5 key measurements described by competence development levels (Tables 2-7). 
Table 2. "Professionally important personal qualities of a teacher" competence cluster indicators (compiled by the author)

\begin{tabular}{|c|c|c|c|}
\hline \multirow{2}{*}{$\begin{array}{l}\text { Competency } \\
\text { group }\end{array}$} & \multicolumn{3}{|c|}{ Indicators according to certification levels (of competence development) } \\
\hline & $\begin{array}{l}\text { Highest } \\
\text { (skill level) }\end{array}$ & $\begin{array}{l}\text { Average } \\
\text { (level of experience) }\end{array}$ & $\begin{array}{l}\text { Basic (threshold) } \\
\text { level }\end{array}$ \\
\hline \multirow[t]{4}{*}{ Impact } & $\begin{array}{l}\text { Enjoys respect and full trust of } \\
\text { colleagues, parents, students, } \\
\text { administration, colleagues } \\
\text { from other institutions, and } \\
\text { other specialists. Colleagues } \\
\text { and parents often address the } \\
\text { teacher for advice and help in } \\
\text { solving problems }\end{array}$ & $\begin{array}{l}\text { Enjoys the trust of } \\
\text { colleagues, students, } \\
\text { parents. Willing to } \\
\text { share experience, } \\
\text { knowledger with } \\
\text { colleagues; advise } \\
\text { parents }\end{array}$ & $\begin{array}{l}\text { Realizes the value of } \\
\text { experience, the } \\
\text { knowledge that other } \\
\text { specialists have, only } \\
\text { when personally needs } \\
\text { this knowledge. } \\
\text { Rarely communicates } \\
\text { with parents }\end{array}$ \\
\hline & $\begin{array}{l}\text { Always fair in relation to } \\
\text { students and colleagues }\end{array}$ & $\begin{array}{l}\text { Strive to be honest and } \\
\text { fair }\end{array}$ & $\begin{array}{l}\text { From time to time, the } \\
\text { administration receives } \\
\text { complaints about the } \\
\text { teacher. Works on errors } \\
\text { in behavior, responding } \\
\text { to the environment's } \\
\text { reaction }\end{array}$ \\
\hline & $\begin{array}{l}\text { Creates an atmosphere of } \\
\text { trust and psychological } \\
\text { comfort (including situations } \\
\text { where colleagues or students } \\
\text { provoke irritation). Controls } \\
\text { feelings and impulses }\end{array}$ & $\begin{array}{l}\text { Strives to prevent } \\
\text { impulsive behavior in } \\
\text { relations with } \\
\text { colleagues, students } \\
\text { and parents. Not } \\
\text { always remains calm } \\
\text { and prudent in stress }\end{array}$ & $\begin{array}{l}\text { Can emotionally respond } \\
\text { to critical statements } \\
\text { from colleagues, parents, } \\
\text { behavior of students. } \\
\text { Analyzes mistakes and } \\
\text { works on their } \\
\text { elimination. Under stress, } \\
\text { can be in a depressed } \\
\text { mood }\end{array}$ \\
\hline & $\begin{array}{l}\text { When speaking out energizes } \\
\text { colleagues, students, fully } \\
\text { capturing their attention. } \\
\text { Invariably persuasive. } \\
\text { Cleverly uses humor, verbal } \\
\text { and non-verbal means of } \\
\text { communication }\end{array}$ & $\begin{array}{l}\text { Able to perform at } \\
\text { lessons, parent } \\
\text { meetings and teachers' } \\
\text { councils. Usually } \\
\text { confident when } \\
\text { speaking to students } \\
\text { and colleagues. Has no } \\
\text { special problems with } \\
\text { maintaining discipline } \\
\text { in the classroom }\end{array}$ & $\begin{array}{l}\text { Depending on the topic } \\
\text { under discussion, } \\
\text { requires efforts to } \\
\text { convince colleagues of } \\
\text { the rightness of opinions } \\
\text { or to interest students. } \\
\text { Sometimes struggles to } \\
\text { maintain discipline in the } \\
\text { classroom during lessons }\end{array}$ \\
\hline \multirow{2}{*}{$\begin{array}{l}\text { Self- } \\
\text { development } \\
\text { and } \\
\text { self- } \\
\text { organization }\end{array}$} & $\begin{array}{l}\text { Offers alternative ideas, non- } \\
\text { standard approaches to } \\
\text { solving professional problems }\end{array}$ & $\begin{array}{l}\text { From time to time, } \\
\text { takes initiatives to } \\
\text { improve r school } \\
\text { activities }\end{array}$ & $\begin{array}{l}\text { Needs specific guidance } \\
\text { on what needs to be } \\
\text { changed in activities. } \\
\text { Rarely shows initiative }\end{array}$ \\
\hline & $\begin{array}{l}\text { Serves as an example for } \\
\text { colleagues, students in time } \\
\text { and workplace management }\end{array}$ & $\begin{array}{l}\text { Punctual, "keeps his or } \\
\text { her word", contacts } \\
\text { with } \quad \text { parents. } \\
\text { Accurately keeps } \\
\text { documentation, keeps } \\
\text { order in the office }\end{array}$ & $\begin{array}{l}\text { Dawdles on solutions } \\
\text { following communication } \\
\text { with parents, on problems } \\
\text { of filling out } \\
\text { documentation, etc. Does } \\
\text { not always show } \\
\text { punctuality }\end{array}$ \\
\hline
\end{tabular}


Openly expresses
pedagogical position, which finds understanding among others. Constantly knowledge and helps his or her colleagues to improve

Openly admits his or her mistakes and failures. Positively perceiving other people, can ask them for help

$\begin{array}{ll}\text { Interaction } & \text { Shows (in behavior) an } \\ & \text { understanding of unspoken } \\ & \text { feelings, moods, thoughts of } \\ & \text { other people and their } \\ \text { influence on relations. Has } \\ \text { empathy with others and } \\ \text { understands other people }\end{array}$

Sincerely appreciates the abilities, experience, knowledge of colleagues, students, parents, recognizes their point of view. Has no habit of interrupting, actively listens to understand the meaning of what is said by others

Uses a strategy of cooperation and negotiation in resolving pedagogical and interpersonal conflicts. Finds a touch point that suits everyone
Participates

discussions of school problems

pedagogical activities.

Expresses an opinion of value to colleagues

Calmly reacts to constructive criticism and feedback about his or her work. Openly shows the desire to develop professional skills

Analyzes feelings,
experiences, behavior of other people. Listens to advice from other people (colleagues, students, parents). Shows a benevolent attitude towards students

Readiness to listen to opinions that contradict with own ideas on how to proceed

In resolving conflicts, often tries to reach an agreement (sacrifices something in favor of the other party), or retreats to maintain trust and harmony in relations

Aimed at maintaining
good relations with
colleagues and parents
to achieve positive
results in professional
activities

Rarely expresses position on the problems of educational activities. Sometimes shares his or her knowledge and experience with colleagues

Painfully responds to the comments. When communicating with the administration or colleagues displays readiness to admit mistakes and failures Considers feelings and mood of other people under the influence of the environment. Confident in the relevance of his or her own understanding of pedagogical communication

Tends to think that respect for students and discipline in the class can be achieved based on strict rules. Generally insists on the relevance of opinion or shows uncertainty in communication with others

In a conflict situation, either applies power in relation to students, persistently seeks recognition from colleagues or agrees with the opinions of others, refrains from the discussion

Gives an example of
respectful, sympathetic and
comradely attitude towards
colleagues. Sets a high value
on close human relations, not
limited to the framework of
school. Spends time listening
to the problems of students,
parents, colleagues

Maintains equal relations with particular colleagues, students, parents. Sometimes shows misunderstanding or provokes conflict situ ations 
Table 3. "Information basis for the teacher's activities" competence cluster (compiled by the author)

\begin{tabular}{|c|c|c|c|}
\hline \multirow{2}{*}{$\begin{array}{l}\text { Compete } \\
\text { ncy } \\
\text { group }\end{array}$} & \multicolumn{3}{|c|}{ Indicators according to certification levels (of competence development) } \\
\hline & $\begin{array}{l}\text { Highest } \\
\text { (skill level) }\end{array}$ & $\begin{array}{l}\text { Average } \\
\text { (level of experience) }\end{array}$ & $\begin{array}{l}\text { Basic (threshold) } \\
\text { level }\end{array}$ \\
\hline \multirow[t]{6}{*}{$\begin{array}{l}\text { Informati } \\
\text { on basis } \\
\text { of activity }\end{array}$} & $\begin{array}{l}\text { Forms norms and values of } \\
\text { pedagogical culture: 1) orientation to } \\
\text { the needs of students and their } \\
\text { parents; 2) mutual trust in the team } \\
\text { and exchange of experience and } \\
\text { knowledge; 3) helping students, } \\
\text { parents, colleagues }\end{array}$ & $\begin{array}{l}\text { Cooperates with } \\
\text { parents, students and } \\
\text { colleagues. } \\
\text { Demonstrates } \\
\text { adherence to the norms } \\
\text { and values of a } \\
\text { pedagogical culture }\end{array}$ & $\begin{array}{l}\text { Expresses devotion } \\
\text { to the goals of school } \\
\text { and the values of his } \\
\text { or her profession } \\
\text { verbally. Rarely takes } \\
\text { initiatives to changes } \\
\text { and overcoming } \\
\text { school problems }\end{array}$ \\
\hline & $\begin{array}{l}\text { Has a broad vision that goes beyond } \\
\text { its subject area. Pays significant } \\
\text { attention to educational issue } \\
\text { transcending the subject, to students' } \\
\text { development }\end{array}$ & $\begin{array}{l}\text { Proficient in the content } \\
\text { of the subject, } \\
\text { interested in the latest } \\
\text { achievements, } \\
\text { understands } \\
\text { intersubject the } \\
\text { connections of teached } \\
\text { subject with other } \\
\text { subjects }\end{array}$ & $\begin{array}{l}\text { Knows the theoretical } \\
\text { basis of his or her } \\
\text { subject. Represents } \\
\text { the role and place of } \\
\text { the subject in the } \\
\text { school system. } \\
\text { Implements training } \\
\text { in relevant programs } \\
\text { and textbooks }\end{array}$ \\
\hline & $\begin{array}{l}\text { Familiar with the latest pedagogical } \\
\text { innovations. Creatively recycles } \\
\text { innovative experience, applies it in } \\
\text { activities, acts as a mentor }\end{array}$ & $\begin{array}{l}\text { Familiar with the } \\
\text { regional experience of } \\
\text { teaching the subject, of } \\
\text { which informs the } \\
\text { colleagues at the } \\
\text { methodical association. } \\
\text { Uses the positive } \\
\text { experience of } \\
\text { colleagues in his or her } \\
\text { activities }\end{array}$ & $\begin{array}{l}\text { Familiar with the } \\
\text { teaching methods } \\
\text { used by colleagues }\end{array}$ \\
\hline & $\begin{array}{l}\text { Uses a variety of Information and } \\
\text { Communications Technologies (ICT), } \\
\text { visualization tools for educational } \\
\text { materials, digital educational } \\
\text { resources and understands when and } \\
\text { how to integrate them into the } \\
\text { educational process }\end{array}$ & $\begin{array}{l}\text { Uses ICT, means of } \\
\text { visualization of } \\
\text { educational materials } \\
\text { and regularly apply } \\
\text { them in the educational } \\
\text { process }\end{array}$ & $\begin{array}{l}\text { Knows the basics of } \\
\text { ICT and visualization } \\
\text { tools for educational } \\
\text { materials and } \\
\text { occasionally uses } \\
\text { them in the } \\
\text { educational process }\end{array}$ \\
\hline & $\begin{array}{l}\text { Uses effective health-saving } \\
\text { technologies in activities and in his or } \\
\text { her daily life }\end{array}$ & $\begin{array}{l}\text { Protects students' life } \\
\text { and health in the } \\
\text { educational process }\end{array}$ & $\begin{array}{l}\text { Applies the rules on } \\
\text { labor protection and } \\
\text { fire safety }\end{array}$ \\
\hline & $\begin{array}{l}\text { Understands the social situation in } \\
\text { the classroom (social status of the } \\
\text { students, distribution of roles, } \\
\text { sympathies and antipathies). } \\
\text { Achieves effective interaction } \\
\text { between students to achieve } \\
\text { pedagogical goals }\end{array}$ & $\begin{array}{l}\text { Aware of the social } \\
\text { situation in the class, } \\
\text { knows and considers } \\
\text { students relations }\end{array}$ & $\begin{array}{l}\text { Sometimes has } \\
\text { problems in the } \\
\text { management of } \\
\text { relations between } \\
\text { students }\end{array}$ \\
\hline
\end{tabular}


Table 4. "Development of activity programs and adoption of pedagogical decisions" competence cluster (author's development)

\begin{tabular}{|c|c|c|c|}
\hline \multirow{2}{*}{$\begin{array}{l}\text { Competency } \\
\text { group }\end{array}$} & \multicolumn{3}{|c|}{ Indicators according to certification levels (of competence development) } \\
\hline & $\begin{array}{l}\text { Highest } \\
\text { (skill level) }\end{array}$ & $\begin{array}{l}\text { Average } \\
\text { (experience level) }\end{array}$ & $\begin{array}{l}\text { Baseline } \\
\text { (threshold) level }\end{array}$ \\
\hline \multirow{3}{*}{$\begin{array}{l}\text { Developing } \\
\text { programs of } \\
\text { activities and } \\
\text { adoption of } \\
\text { pedagogical } \\
\text { decisions }\end{array}$} & $\begin{array}{l}\text { Independently develops } \\
\text { program, methodological } \\
\text { and didactic materials and } \\
\text { (or) author's lessons on } \\
\text { subject }\end{array}$ & $\begin{array}{lr}\text { Rationally } & \text { chooses } \\
\text { programs } & \text { and } \\
\text { educational } & \text { and } \\
\text { methodological } & \\
\text { support } & \end{array}$ & $\begin{array}{l}\text { Provides a prospective } \\
\text { thematic planning for a } \\
\text { quarter, an academic year. } \\
\text { Prepares plans for the } \\
\text { lessons }\end{array}$ \\
\hline & $\begin{array}{l}\text { Effectively resolves } \\
\text { problems of educational } \\
\text { activity. Shares thoughts } \\
\text { with colleagues about a } \\
\text { certain situation, sees in } \\
\text { them not only threats but } \\
\text { also favorable opportunities }\end{array}$ & $\begin{array}{l}\text { Coordinates feelings } \\
\text { and thoughts with the } \\
\text { changing } \\
\text { pedagogical situation } \\
\text { and position of other } \\
\text { people }\end{array}$ & $\begin{array}{l}\text { Demonstrates a desire to } \\
\text { participate in the changes } \\
\text { under the guidance of } \\
\text { administration } \\
\text { colleagues. } \\
\text { Finds solutions to } \\
\text { pedagogical problems by } \\
\text { interacting with colleagues }\end{array}$ \\
\hline & $\begin{array}{l}\text { Initiates a discussion of } \\
\text { complex (controversial) } \\
\text { learning problems in the } \\
\text { classroom and carries } \\
\text { out, together with the } \\
\text { students, verification of } \\
\text { selected options during } \\
\text { the educational process }\end{array}$ & $\begin{array}{l}\text { Forms students' } \\
\text { skills in the analysis } \\
\text { of educational } \\
\text { problems and } \\
\text { decision-making } \\
\text { process }\end{array}$ & $\begin{array}{l}\text { Uses typical (standard) } \\
\text { tasks in the educational } \\
\text { process. Sometimes uses } \\
\text { examples of solving } \\
\text { research problems during } \\
\text { the educational process }\end{array}$ \\
\hline
\end{tabular}

Table 5. "Motivation of training activities" competence cluster (author's development)

\begin{tabular}{|c|c|c|c|}
\hline \multirow{6}{*}{$\begin{array}{l}\text { Cluster } \\
\text { (group) of } \\
\text { competenci } \\
\text { es } \\
\text { Motivation } \\
\text { of training } \\
\text { activities }\end{array}$} & \multicolumn{3}{|c|}{ Indicators according to certification levels (of competence development) } \\
\hline & $\begin{array}{l}\text { Highest } \\
\text { (skill level) }\end{array}$ & $\begin{array}{l}\text { Average } \\
\text { (experience level) }\end{array}$ & $\begin{array}{l}\text { Baseline } \\
\text { (threshold) level }\end{array}$ \\
\hline & \multirow{2}{*}{$\begin{array}{l}\text { In the classroom, } \\
\text { considers educational } \\
\text { problems of the subject } \\
\text { with regard to the modern } \\
\text { achievements of science } \\
\text { and technology in the } \\
\text { subject area }\end{array}$} & \multirow{2}{*}{$\begin{array}{l}\text { Uses the content of the } \\
\text { subject and changes } \\
\text { teaching methods } \\
\text { depending on a } \\
\text { pedagogical situation, } \\
\text { provides a link between } \\
\text { theory and practice }\end{array}$} & \multirow{3}{*}{$\begin{array}{l}\text { Knows recommended } \\
\text { approaches to presenting } \\
\text { the content of the subject } \\
\text { and teaching methods. } \\
\text { Manages teaching } \\
\text { process in accordance } \\
\text { with the guidelines } \\
\text { Works on improving skills } \\
\text { in teaching the subject, } \\
\text { master modern } \\
\text { pedagogical technologies }\end{array}$} \\
\hline & & & \\
\hline & $\begin{array}{l}\text { Encourages students' } \\
\text { creativity, initiative and } \\
\text { independence, believes in } \\
\text { their potential and focuses } \\
\text { on humanistic learning }\end{array}$ & $\begin{array}{l}\text { Applies modern } \\
\text { pedagogical technologies } \\
\text { (active learning, ICT, } \\
\text { design, research) in the } \\
\text { process of teaching }\end{array}$ & \\
\hline & $\begin{array}{l}\text { Shows a genuine interest } \\
\text { in other people, considers } \\
\text { assistance to be the most } \\
\text { important value of the } \\
\text { pedagogical profession. }\end{array}$ & $\begin{array}{l}\text { Ready to help colleagues } \\
\text { and students, rejoices at } \\
\text { students' success }\end{array}$ & $\begin{array}{l}\text { Interested in the problems } \\
\text { of the colleagues from } \\
\text { time to time, rejoices at } \\
\text { the success of particular } \\
\text { students, who are }\end{array}$ \\
\hline
\end{tabular}




\begin{tabular}{|c|c|c|}
\hline $\begin{array}{l}\text { Always is ready to help, } \\
\text { sincerely rejoices at } \\
\text { success of all students and } \\
\text { achievements of the } \\
\text { colleagues }\end{array}$ & & $\begin{array}{l}\text { sympathetic to him or her } \\
\text { or who are successful in } \\
\text { their studies }\end{array}$ \\
\hline $\begin{array}{l}\text { Knows the hidden needs of } \\
\text { students and their parents; } \\
\text { works on their satisfaction; } \\
\text { attentive to inquiries, } \\
\text { complaints, equally } \\
\text { accessible to "weak" and } \\
\text { "strong" students; } \\
\text { confident that students are } \\
\text { able to change }\end{array}$ & $\begin{array}{l}\text { Aware of students' and } \\
\text { their parents' needs, } \\
\text { makes extra efforts to } \\
\text { respond promptly to the } \\
\text { requests of parents and } \\
\text { students, tends to make } \\
\text { teaching materials } \\
\text { understandable for } \\
\text { students }\end{array}$ & $\begin{array}{l}\text { Focused on theirselves } \\
\text { and the current problems } \\
\text { of educational activity. } \\
\text { Due to the concentration } \\
\text { of efforts on organization } \\
\text { of the teaching process, } \\
\text { not always responsive to } \\
\text { parents' or colleagues' } \\
\text { requests }\end{array}$ \\
\hline $\begin{array}{l}\text { Experiences satisfaction } \\
\text { (true pleasure) from } \\
\text { teaching work. } \\
\text { Completely loyal to } \\
\text { profession, school, and } \\
\text { colleagues }\end{array}$ & 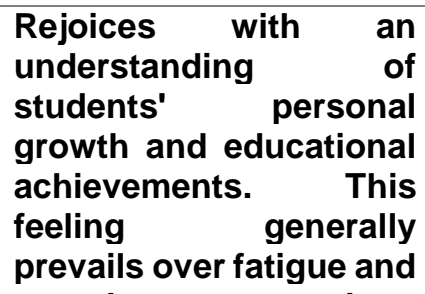 & $\begin{array}{l}\text { Clearly fulfills teacher's } \\
\text { duties in subject area. } \\
\text { Sometimes expresses } \\
\text { dissatisfaction with the } \\
\text { difficulties of teacher's } \\
\text { work. Strives to show a } \\
\text { positive attitude towards }\end{array}$ \\
\hline & \begin{tabular}{lcc} 
negative & \multicolumn{2}{c}{ emotions } \\
associated & with the \\
difficulties & of the \\
profession & &
\end{tabular} & \\
\hline
\end{tabular}

Table 6. "Organization of educational activities" competence cluster (author's development)

\begin{tabular}{|c|c|c|c|}
\hline \multirow{2}{*}{$\begin{array}{l}\text { Group of } \\
\text { competence } \\
s\end{array}$} & \multicolumn{3}{|c|}{ Indicators according to certification levels (of competence development) } \\
\hline & Highest (skill level) & Average (experience level) & $\begin{array}{l}\text { Baseline (threshold) } \\
\text { level }\end{array}$ \\
\hline \multirow[t]{4}{*}{$\begin{array}{l}\text { Organizatio } \\
\mathbf{n} \quad \text { of } \\
\text { learning } \\
\text { activities }\end{array}$} & $\begin{array}{l}\text { Demonstrates the standard } \\
\text { of teacher's behavior - } \\
\text { intelligence, tact, endurance, } \\
\text { high general culture }\end{array}$ & $\begin{array}{l}\text { Tends to demonstrate the } \\
\text { best qualities of a teacher }\end{array}$ & $\begin{array}{l}\text { Strives to follow the } \\
\text { behavior patterns of the } \\
\text { best teachers in school. } \\
\text { In difficult situations, } \\
\text { encounters a lack of } \\
\text { understanding } \\
\text { surrounding people }\end{array}$ \\
\hline & $\begin{array}{l}\text { Inspires students with own } \\
\text { example. The authority is }\end{array}$ & $\begin{array}{l}\text { Ready to discuss some } \\
\text { educational problems with }\end{array}$ & $\begin{array}{l}\text { Requires students to } \\
\text { participate in the lesson }\end{array}$ \\
\hline & $\begin{array}{l}\text { based on influence and skills } \\
\text { of interpersonal relations. } \\
\text { Uses a democratic style of } \\
\text { class management }\end{array}$ & $\begin{array}{l}\text { students, } \\
\text { opportunities for joint } \\
\text { research in small study } \\
\text { groups. } \quad \text { Effectively } \\
\text { organizes independent } \\
\text { work of students }\end{array}$ & $\begin{array}{l}\text { (answering the } \\
\text { questions, speaking out, } \\
\text { playing games). From } \\
\text { time to time, declines } \\
\text { students' requests, } \\
\text { confronts them }\end{array}$ \\
\hline & 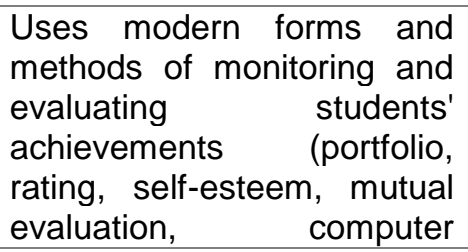 & $\begin{array}{l}\text { Uses a variety of forms } \\
\text { and methods of control. } \\
\text { Gives grades based on } \\
\text { clear evaluation criteria } \\
\text { familiar, to students. } \\
\text { Depending on the learning }\end{array}$ & $\begin{array}{l}\text { Uses traditional forms } \\
\text { and methods of control. } \\
\text { To evaluate students } \\
\text { mainly uses grades, } \\
\text { lesson and quaternary } \\
\text { control. Frequently }\end{array}$ \\
\hline
\end{tabular}


technology, etc.). Pays more attention to the integrated assessment of the quality of education (education, upbringing, development), not only to evaluation of the training level in the form of scores (test results)

Organizes the educational process based on respect for human dignity, honor and reputation of students

\section{goals, choose forms and methods of control and types of tasks. Understands and uses educational opportunities for students' evaluation}

Respects the rights and $\begin{aligned} & \text { Observes the schedule } \\ & \text { freedoms of students, and }\end{aligned}$ students'
creates a working attendance. Sometimes
atmosphere in the has problems
classroom, supports the maintaining discipline in
academic discipline

gives grades based on intuition, with a high degree of subjectivity

Table 7. "Setting goals and objectives of educational activity" competence cluster (author's development)

\begin{tabular}{|c|c|c|c|}
\hline \multirow{2}{*}{$\begin{array}{l}\text { Group } \\
\text { of } \\
\text { competence } \\
\text { s }\end{array}$} & \multicolumn{3}{|c|}{ Indicators according to certification levels (of competence development) } \\
\hline & Highest (skill level) & Average (experience level) & Baseline (threshold) \\
\hline \multirow[t]{3}{*}{$\begin{array}{l}\text { Setting } \\
\text { goals and } \\
\text { objectives } \\
\text { of the } \\
\text { educational } \\
\text { activity }\end{array}$} & $\begin{array}{l}\text { Forms a string of logic from } \\
\text { the Federal State Education } \\
\text { Standards requirements of } \\
\text { general (primary) education } \\
\text { to the measurable goals of } \\
\text { subject and each specific } \\
\text { lesson. Considers students' } \\
\text { individual and age } \\
\text { characteristics }\end{array}$ & $\begin{array}{l}\text { While defining goals of the } \\
\text { educational process, } \\
\text { equally pays attention to } \\
\text { educational and } \\
\text { developmental goals. } \\
\text { Sometimes has difficulties } \\
\text { in measuring formulated } \\
\text { goals }\end{array}$ & $\begin{array}{l}\text { Formulates objectives } \\
\text { only at the level of } \\
\text { lesson planning, giving } \\
\text { priority to the learning } \\
\text { objectives }\end{array}$ \\
\hline & $\begin{array}{l}\text { Involves learners in the } \\
\text { process of formulating } \\
\text { (understanding) learning } \\
\text { goals and tasks (on specific } \\
\text { topics) }\end{array}$ & $\begin{array}{l}\text { Helps students understand } \\
\text { the goals and tasks of the } \\
\text { lesson, for example, by } \\
\text { summing up the results } \\
\text { during the lesson }\end{array}$ & $\begin{array}{l}\text { Periodically } \\
\text { students how they } \\
\text { understand the goals } \\
\text { and tasks of the lesson }\end{array}$ \\
\hline & $\begin{array}{l}\text { Concerned about the } \\
\text { improvement of actions } \\
\text { and results. In the process } \\
\text { of activity, constantly } \\
\text { correlates the goals and } \\
\text { achieved results. Based on } \\
\text { the results of "internal" } \\
\text { analysis, independently } \\
\text { implements changes in the } \\
\text { objectives and (or) actions }\end{array}$ & $\begin{array}{l}\text { Realizes the level of } \\
\text { achievement of the goals } \\
\text { after receiving some } \\
\text { negative "signs", results } \\
\text { of a periodic control or } \\
\text { parents' requests. } \\
\text { Determines actions to } \\
\text { change the situation } \\
\text { improving actions and } \\
\text { results }\end{array}$ & $\begin{array}{l}\text { Guides in activities by } \\
\text { the goals set in } \\
\text { methodological } \\
\text { (instructive) materials. } \\
\text { Does not always analyze } \\
\text { the level of achievement } \\
\text { of expected goals in the } \\
\text { educational process }\end{array}$ \\
\hline
\end{tabular}

The indicators for teachers' evaluation (the second component of the mixed model) reflected both the requirements of Russian Federal Educational Standards and features of the regional education system. Below one can see indicator groups of results of the teacher's evaluation in a secondary general school using Moscow as an example: 
Group: Knowledge of students (including Dynamics of possibilities of classes in which the teacher works, Students' participation in contests and competitions).

Group: Methodical work (Modern methods, Generalization of pedagogical experience, Efficiency of teacher's participation in programs of self-training, professional development)

Group: Out-of-class (extracurricular) activity (such as the Efficiency of organizing extracurricular activities)

Group: Educational work (Teacher's work with parents, collaborative activity of the teacher together with his/her class, Teacher's job of maintaining discipline in a class and creating a comfortable psychological situation in the classroom, class teacher's work: maintaining discipline in the classroom).

As an illustration to the way of organizing teachers' professional development based on the developed assessment tools, Figure 1 shows an example of teacher's competence profile in terms of "Basic Competencies" cluster and Figure 2 in terms of "Performance Results". Profiles were generated by HRMS, where GES leaders and mentors could see indicators, which are of paramount importance to a particular teacher and therefore should be incorporated in the program of professional development (Figures 1, 2).

Evaluation protocol of professional qualities and performance results Average profile of 360 degree evaluation of teacher's competencies (-0-0-), the self-esteem schedule ( - - - )

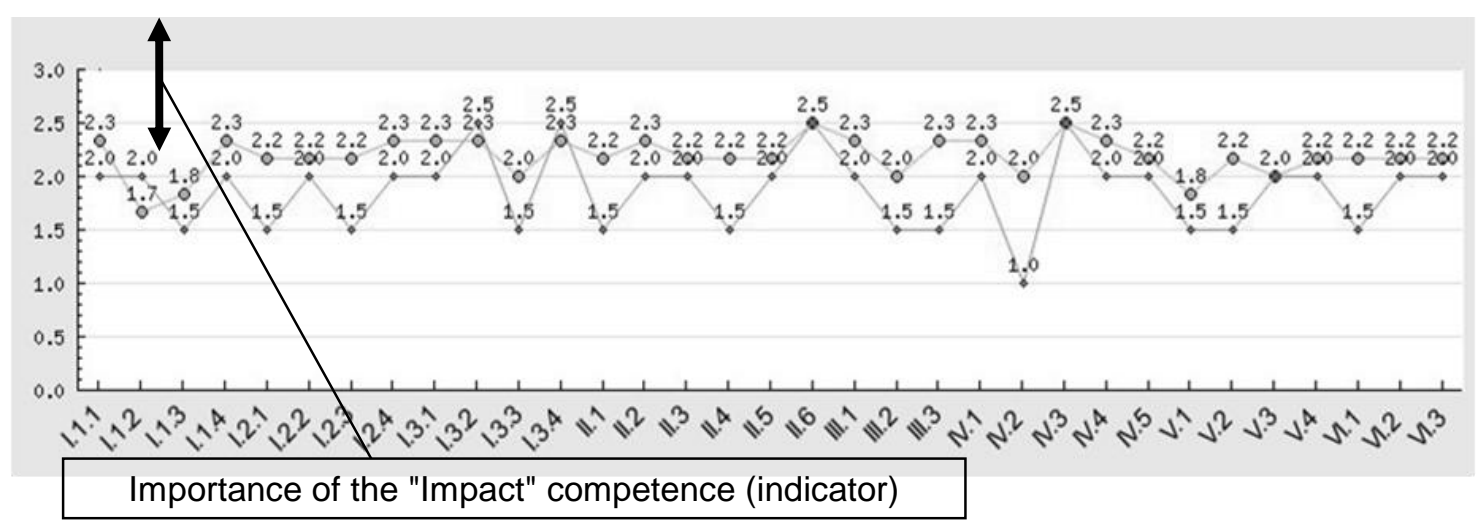

Figure 1. Teacher's competence profile in terms of "Professional qualities" indicating the importance of particular measurement (source: copies of results obtained with HRMS created by the author in the research process)

Note: the lower curve is the teacher's self-esteem; the upper curve is the average score of all respondents including the score of the teacher, who participated in certification. The 
importance of competence (specific indicator) is the discrepancy between the actual (based on the assessment) and the maximum (skill level) behavior and results of a specialist

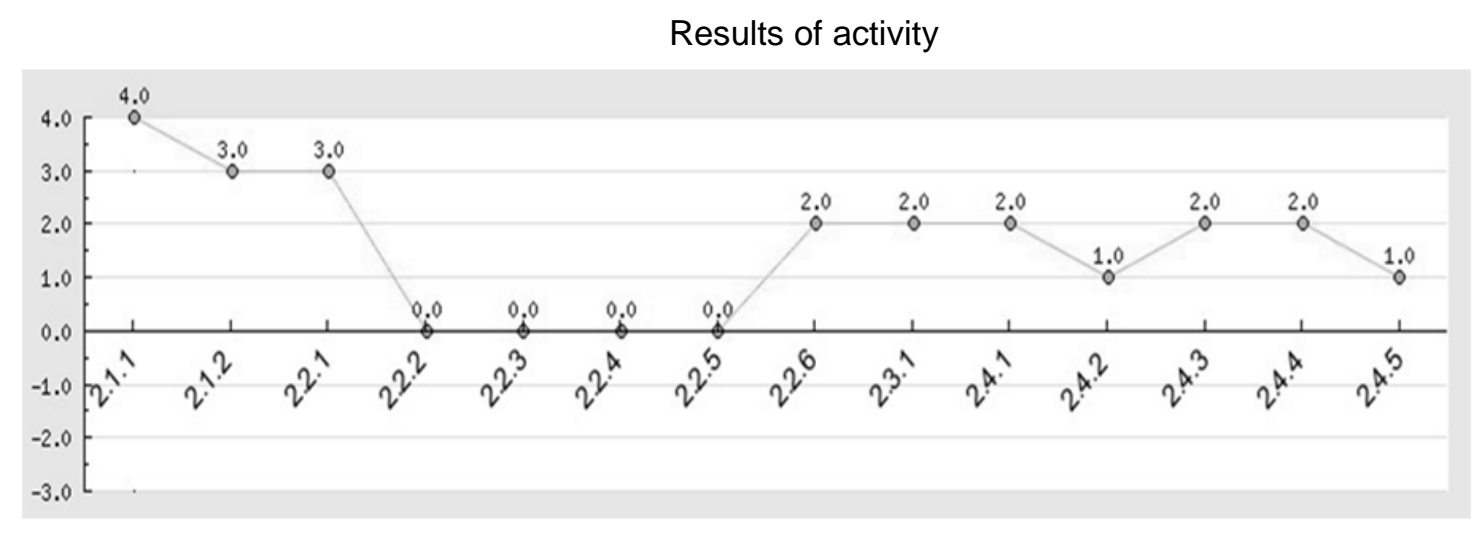

Figure 2. Performance profile source: copies of results obtained with the HRMS created by the author in the research process).

Note: Measurements that require a teacher to work on himself or herself: 2.2.2-2.2.4, generalization of pedagogical experience; 2.2.5, participation in scientific and methodological grants.

The degree of teachers' acceptance of the created evaluation tools and techniques was based on an anonymous survey of the Moscow school teachers participating in the pilot activities to create a personnel management system in educational organizations. $78.0 \%$ of the respondents answered affirmatively to the question "Do the methods developed for evaluation of school personnel allow determining the level of teacher's qualifications based professional qualities and performance results?" $77.0 \%$ of the teachers who participated in the survey replied positively to the question "Do the methods developed for teachers' evaluation allow identifying problem areas in the profile of teacher's competencies and planning targeted professional development programs?" These numbers show that most teachers find the mixed model and HRMS useful and the author's approach to teachers' evaluating promotes the ongoing teacher learning.

A mixed model for personnel evaluation is applied abroad, where employees are assessed according to their contribution to professional activities. In the present study, an employee of the Institute of Digital Education of MCU applied this approach to staff evaluation in a non-profit organization (secondary school) and developed the appropriate evaluation tools for measuring professional qualities and results of school teachers' activity. The model refers to the teacher's qualities determining $s$ uccess or failure, thus, the Federal Standard does not define those qualities. If the context changes, the teacher will adjust and become successful. 
Yury Frolov.

The model consists of groups of competences and groups of indicators allowing to estimate the level of necessary and sufficient qualities and results of teacher's activity. An important purpose of distinguishing different levels of competence is to stimulate teachers for constant professional development in the interests of their own career growth, school effectiveness and upbringing and education of students.

This study differs from the others focused on the content of HRM ("which HR methods lead to certain results?") and the HRM process itself (exploring attitudes to the HRM) offering both the evaluation system and its acceptance. Evaluation tools are complemented by formation of a constantly updated database in an educational organization in accordance with the structure of indicators. The results achieved by each teacher are open and accessible to all teachers. Scoring indicators describe teachers' behavioral response to interacting with their colleagues (students and their parents) for each of the three selected levels of professional competencies.

The study confirmed that the constant process of measuring and forming professional profiles is a prerequisite for the creation of professional development programs and selfdevelopment of teachers in the educational organization. The proposed model, integrating the indicators of professionalism, the most important of which are the differentiating competences, was proved in the course of the experiment. Most teachers note that they have acquired additional pedagogical knowledge and skills. They learned more about themselves and teaching methods used due to the evaluation system, which shows the dynamics of their competencies development and results that in a graphical form that simplifies the choice of directions for further professional self-improvement. Similar results were obtained during the application of The Performance Assessment for California Teachers (PACT) focused on teachers' training (Darling-Hammond et al., 2013), exchanging their knowledge with colleagues (Runhaar and Sanders, 2015). School rating depends on the effectiveness of its teachers and students (Croft, 2015), which determines quantity and quality of students' preparation, with a certain degree of readiness and the type of motivation of those entering each specific school.

Since findings are of interest to all the concerned parties of an educational process, the differentiating competencies given in the model can form the basis for teachers' evaluation who aspire professional qualifications as "experts" and "masters". Average competencies presented in the models serve as a basis for teachers' evaluation in terms of experience. Threshold competencies should be included in the descriptions of teachers' qualifications certified for compliance with their position.

With regard to other evaluation systems, teachers estimate the subject-based standards of performance and feedback as enhancing capabilities in the event of transition to CCSS (Fenwick, 2016). This proves the idea that the importance of HRM has grown from the level of external management (control) of teaching staff (measurement of results) to the level of professional development system actively used by teachers themselves (Mossholder et al, 2011). 
The created in the course of the experiment HRMS (Certificate of registration of computer programs No. 2011617347 dated September 21, 2011) automated the process of circular estimation. HRMS counted ratings of each teacher; they reflected the degree of development of their professional qualities and the level of pedagogical results achieved. At the output, the system gave printouts with the number of incentive payments to teachers.

Due to time and resource constraints, the study was limited to 46 educational organizations in Moscow over 6 years in the course of the experiment which is sufficient to create the evaluation model for central and most developed cities. It would be helpful to compare data from the regional educational institutions to identify regional specificities, if any, and improve the model obtained. Features of the research procedure could have such consequences as pressure on those who filled out the questionnaire during working hours; future studies may include the analysis of these effects.

\section{Conclusions}

To ensure the readiness of school management and teachers for transition to the normative per capita financing the author developed an HRM based on the concept of a mixed model of staff evaluation and the principles of openness and clarity. It contains tools for measuring both formalized results and professional competence of teachers. Teachers' professional development did not escape the author's attention since as an aspect of human capital it is linked to financial results and has superiority over them.

The evaluation model and the HRMS, developed in the course and based on the experiment results, which automates the processes of evaluation and distribution of incentive payments, has been successfully tested and evaluated by teachers as "effective". The system is easy to use and allows estimating the level of competencies and results achieved over time, and therefore, useful in preparing for teachers' certification. It is also beneficial to students when preparing for classes (and indirectly to their parents, who often apply for expensive tuition services).

The research identified and confirmed behavioral indicators on three levels of competence development - threshold, experience, and skill method - in each cluster. Each group of competencies is estimated in accordance with the minimum necessary and sufficient indicators.

\section{References}

Andreeva, T. and Sergeeva, A. (2016) The more the better... or is it? The contradictory effects of HR practices on knowledge-sharing motivation and behavior. Human Resource Management Journal, 26(2), 151-171, https://doi.org/10.1111/17488583.12100 
Armstrong, M. and Baron, A. (1998) Performance Management: The new realities. London: CIPD.

Backes, B., Cowana, J., Goldhabera, D., Koedelb, C., Millerc, L. C. and Xu, Z. (2018). The common core conundrum: To what extent should we worry that changes to assessments will affect test-based measures of teacher performance? Economics of Education Review, 62, 48-65, https://caldercenter.org/sites/default/files/Working\%20Paper\%20152.pdf

Berger, D. R., and Berger, L. A. (2000). The compensation handbook. Columbus: McGraw-Hill.

Çevik, Y. D., Haşlaman, T. and Çelik, S. C. (2015). The effect of peer assessment on problem solving skills of prospective teachers supported by online learning activities. Studies in Educational Evaluation, 44, 23-35, https://doi.org/10.1016/j.stueduc.2014.12.002

Chang, K. (2013). With common core, fewer topics but covered more rigorously. The New York Times, Sept. 3, 2013, Section D, Page 2, https://www.nytimes.com/2013/09/03/science/fewer-topics-covered-morerigorously.html

Chianese, G. (2015). Developing and assessing teaching effectiveness. Procedia Social And Behavioral Sciences, Volume 191, 692-695, https://doi.org/10.1016/j.sbspro.2015.04.218

Croft, M. and Buddin, R. (2015). The legality of using school-wide growth measures in teacher. Act Research \& Policy. lowa, IA: ACT Inc.

Darling-Hammond, L., Newton, S. P. and Wei, R. C. (2013). Developing and assessing beginning teacher effectiveness: the potential of performance assessments. Educational Assessment, Evaluation and Accountability, 25, 179-204, https://edpolicy.stanford.edu/sites/default/files/publications/developing-and-

assessing-beginning-teacher-effectiveness-potential-performanceassessments.pdf

Fenwick, L. (2016). Promoting assessment for learning through curriculum-based performance standards: teacher responses in the Northern Territory of Australia. The Curriculum Journal, 28(1), 41-58, https://doi.org/10.1080/09585176.2016.1260486

Hubert, R.K. (2003). Total performance scorecard. Redefining management to achieve performance with integrity. Oxford: Butterworth-Heinemann.

Lawson, P. (1995). Performance management: an overview. In: M. Walters (ed.). Performance Management Handbook. London: CIPD.

Mariappanadar, S. (2014) The model of negative externality for sustainable HRM. In: Ehnert I., Harry W., Zink K.J. (eds). Sustainability and human resource management. Part of the CSR, sustainability, ethics \& governance. Berlin, Heidelberg: Springer.

Maroufkhani, P., Nourani, M. \& Boerhannoeddin, A. (2015). High-performance work systems and school effectiveness: the case of Malaysian secondary schools. Asia Pacific Education Review, 16, 461-475, https://doi.org/10.1007/s12564-015-93892 
Mossholder, K.W, Richardson, H.A. and Settoon, R.P. (2011). Human resource systems and helping in organizations: A relational perspective. Academy of Management Review, 36 (1), 33-52, https://doi.org/10.5465/amr.2009.0402

Niven, P.R. (2003). Balanced scorecard step-by-step for government and not-for-profit agencies. New York: John Wiley \& Sons.

Parks-Leduc, L., Rutherford, M.A., Becker, K.L. and Shahzad, A.M. (2017). The professionalization of human resource management: Examining undergraduate curricula and the influence of professional organizations. Journal of Management Education, 42(2), 211-238, https://doi.org/10.1177/1052562917727034

Pogodzinski, B. (2016). The microfoundations of human resources management in US public schools. Journal of Educational Administration, 54(5), 537-557, https://doi.org/10.1108/JEA-09-2015-0076

Roberts, G. (1997). Recruitment and selection. A competency approach. London: CIPD.

Runhaar, P. (2017). How can schools and teachers benefit from human resources management? Conceptualising HRM from content and process perspectives. Educational Management Administration \& Leadership, 45(4), 639-656, https://doi.org/10.1177/1741143215623786

Runhaar, P. and Sanders, K. (2015). Promoting teachers' knowledge sharing. The fostering roles of occupational self-efficacy and human resources management. Educational Management Administration \& Leadership, 44(5), 794-813, https://doi.org/10.1177/1741143214564773

Ryabov V., Frolov, Yu. and Masumov, M. (2012). An effective pedagogical worker: evaluate by standard. Kadrovik, 6, 81-89 (in Russian).

Sandholtz, J.H. and Shea, L.M. (2012). Predicting performance: A comparison of university supervisors' predictions and teacher candidates' scores on a teaching performance assessment. Journal of Teacher Education, 63(1), 39-50, https://doi.org/10.1177/0022487111421175

Shadrikov, V.D., and Kuznetsov I.V. (2010). Methodology of Teachers' Evaluation. Moscow: Tsentr pedagogicheskogo obrazovaniya (in Russian).

Shirrell, M. (2016). New principals, accountability, and commitment in low-performing schools. Journal of Educational Administration, 54(5), 558-574, https://doi.org/10.1108/JEA-08-2015-0069

Vekeman, E., Devos, G., \& Tuytens, M. (2015). The influence of teachers' expectations on principals' implementation of a new teacher evaluation policy in Flemish secondary education. Educational Assessment Evaluation and Accountability, 27(2), 129-151, https://doi.org/10.1007/s11092-014-9203-4

Ward, P. (1997). 360-degree feedback. London: CIPD. 